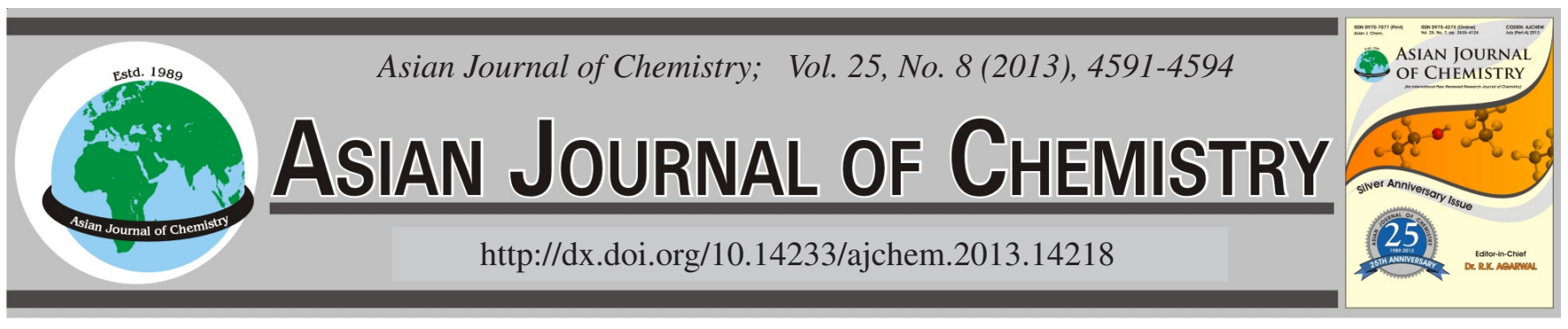

\title{
Hopane and Lupane Triterpenes from Leaves and Stem Bark of Aegle marmelos (Rutaceae)
}

\section{S. AhMAD ${ }^{1}$, S. RiYAnto ${ }^{3}$, M.A. SuKARI ${ }^{1, *}$, M. Rahmani ${ }^{1}$ and A.M. Ali ${ }^{2}$}

\begin{abstract}
${ }^{1}$ Department of Chemistry, Universiti Putra Malaysia, 43400 Serdang, UPM, Selangor Darul Ehsan, Malaysia ${ }^{2}$ Faculty of Agriculture and Biotechnology, UniSZA, 20400 Kuala Terengganu, Terengganu, Malaysia

${ }^{3}$ Faculty of Pharmacy, Gadjah Mada University, Yogyakarta 55581, Indonesia
\end{abstract}

*Corresponding author: E-mail: aspollah@science.upm.edu.my

Two hopane and two lupane triterpenes have been isolated from leaves and stem bark of Aegle marmelos originated from Yogyakarta, Indonesia. Hopane triterpenes identified as $6 \alpha, 22$-dihydroxyhopane (1) and 15 $\alpha, 22$-dihydroxyhopane (2) were isolated from petroleum ether extract of the leaves, while lupane triterpenes; 20(29)-lupene-3 $\alpha$-ol (3) and 20(29)-lupene-3-on (4) were isolated from the stem bark. The structure of the compounds were elucidated using spectroscopic methods and by comparison with previous data.

Key Words: Aegle marmelos, Hopane triterpenes, Lupane triterpenes.

\section{INTRODUCTION}

Aegle marmelos Correa; synonym of Crataeva marmelos Linn. and Crataeva religiosa Ainslie belongs to Rutaceae family $^{1}$ and locally known as bel (Malaysia) and maja (Indonesia). The plant grows easily in Indian Subcontinent and Southeast Asia. The plant is known in traditional medicine uses e.g., the leaves are utilized for treatment of fertility control, the bark is used for diabetes, while the root and aerial part were used in Ayurvedic system in Sri Lanka as medicine for some ailments such as to treat intermittent fever and for fish poison $^{2,3}$. In India the leaves are mostly used in religious offering in temples. The older folks used its half-ripe fruit to relieve dysentery, cholera and constipation ${ }^{4}$. The ripe fruit can be used as a laxative and the extract as for rectum inflammation, whereas the fresh ripe-fruit is made into sherbet or syrup. The fixed oil of seed is used for purgative and claimed to have antimicrobial and anthelminthic activity ${ }^{5}$. Previous phytochemical work on Aegle marmelos have afforded several classes of constituents such as aegeline ${ }^{6}$ and coumarin derivatives $^{6,7}$, cinnamide alkaloids ${ }^{8}$, anthraquinone ${ }^{7}$ and some lignin glycoside $^{9}$. In continuation of our work on Rutaceous and local medicinal plants, here we report phytochemical investigation of leaves and stem barks of Aegle marmelos.

\section{EXPERIMENTAL}

The Infrared spectra were recorded using $\mathrm{KBr}$ mini disc on Perkin Elmer FTIR spectrophotometer model 1725X, while ultraviolet spectra were recorded on Shimadzu UV-VIS 160 Spectrometer in absolute ethanol or methanol. Mass spectra were recorded by AE1-MS 12 spectrometer with ionisation induced by electron impact at $70 \mathrm{eV} .{ }^{1} \mathrm{H}$ NMR $(500 \mathrm{MHz})$ and ${ }^{13} \mathrm{C}$ NMR (125 MHz) spectra were recorded by JEOL FTNMR or Bruker DRX-500 with $\mathrm{CDCl}_{3}$ used as solvent. Melting points were determined by Kohfler melting points apparatus XSP-12 Model 500X equipped with microscope and were uncorrected.

The plant sample of Aegle marmelos was collected from Yogyakarta, Indonesia. The plant was identified by Dr. Suwijio Pramono from Gadjah Mada University, Yogyakarta, Indonesia. The voucher specimen was deposited in the herbarium of Faculty of Pharmacy, Gadjah Mada University.

Isolation of constituents: The ground air-dried leaves $(2.5 \mathrm{~kg})$ and stem bark $(3.5 \mathrm{~kg})$ of the A. marmelos were extracted three times successively with petroleum ether, chloroform and methanol. The leaves extracts were concentrated under reduced pressure using rotary evaporator to give dark gummy solid of petroleum ether $(21 \mathrm{~g})$, chloroform (67.7 $\mathrm{g})$ and methanol (133 g) extracts, respectively while stem bark yielded petroleum ether (14.1 g), chloroform (22.5 g) and methanol $(130 \mathrm{~g})$ extracts, respectively. Each of these extracts was subjected to column chromatography over silica gel using mixtures of petroleum ether, chloroform and methanol as eluents. Column chromatography separation of petroleum ether extract of the leaves (17.8 g) yielded $6 \alpha, 22$-dihydroxyhopane (1, 249 $\mathrm{mg}$ ) and $15 \alpha, 22$-dihydroxyhopane (2,95 mg), while separation 


\begin{tabular}{|c|c|c|c|c|c|c|c|c|}
\hline & \multicolumn{8}{|c|}{$\begin{array}{c}\text { TABLE-1 } \\
\text { NMR DATA OF COMPOUNDS (1) AND (2) }\end{array}$} \\
\hline & \multicolumn{2}{|c|}{${ }^{1} \mathrm{H}$ NMR $(500 \mathrm{MHz}) \mathrm{CDCl}_{3}$} & \multicolumn{2}{|c|}{$\begin{array}{l}{ }^{13} \mathrm{C} \mathrm{NMR}(125 \\
\mathrm{MHz}) \mathrm{CDCl}_{3}\end{array}$} & \multicolumn{2}{|c|}{ COSY } & \multicolumn{2}{|c|}{ HMBC } \\
\hline & (1) & (2) & (1) & (2) & (1) & (2) & (1) & (2) \\
\hline 1 & $0.88, \mathrm{~m}$ & $0.81, \mathrm{~m}$ & 41.4 & 41.1 & $\mathrm{H}-2$ & - & C-25 & - \\
\hline 2 & $1.64, \mathrm{~m}$ & $1.40, \mathrm{~m}$ & 19.4 & 19.5 & H-1 & $\mathrm{H}-3$ & - & - \\
\hline 3 & $1.31, \mathrm{~m}$ & $1.17, \mathrm{~m}$ & 44.8 & 42.6 & - & $\mathrm{H}-2$ & - & - \\
\hline 4 & - & - & 34.6 & 34.3 & - & - & - & C-23, C-24 \\
\hline 5 & $1.12, \mathrm{~m}$ & $0.86, \mathrm{~m}$ & 61.6 & 56.7 & H-6 & - & - & C-7 \\
\hline 6 & $\begin{array}{l}4.23, \mathrm{dt} \\
(\mathrm{J}=10.0,4.5 \mathrm{~Hz})\end{array}$ & $1.59, \mathrm{~m}$ & 68.3 & 21.8 & H-5, H-7 & - & - & - \\
\hline 7 & $1.83, \mathrm{~m}$ & $2.12, \mathrm{~m}$ & 46.2 & 37.7 & - & - & - & $\mathrm{C}-5$ \\
\hline 8 & - & - & 43.4 & 44.2 & - & - & - & - \\
\hline 9 & $1.36, \mathrm{~m}$ & $1.35, \mathrm{~m}$ & 50.7 & 51.5 & - & - & $\mathrm{C}-26$ & $\mathrm{C}-7$ \\
\hline 10 & - & - & 42.6 & 38.3 & - & - & - & - \\
\hline 11 & $1.56, \mathrm{~m}$ & $1.58, \mathrm{~m}$ & 21.1 & 19.8 & - & - & - & - \\
\hline 12 & $1.53, \mathrm{~m}$ & $1.51, \mathrm{~m}$ & 24.8 & 25.1 & - & - & - & - \\
\hline 13 & $1.38, \mathrm{~m}$ & $1.42, \mathrm{~m}$ & 50.2 & 50 & - & - & - & - \\
\hline 14 & - & - & 39.8 & 48.1 & - & - & - & - \\
\hline 15 & $1.29, \mathrm{~m}$ & $\begin{array}{l}4.11, \mathrm{dd} \\
(\mathrm{J}=9.7,5.1 \mathrm{~Hz})\end{array}$ & 35.1 & 74.9 & - & H-16 & - & C-8,C-14,C-16,C-27 \\
\hline 16 & $2.18, \mathrm{~m}$ & $\begin{array}{l}2.80, \text { ddd } \\
(\mathrm{J}=9.7,5.1,2.0 \mathrm{~Hz})\end{array}$ & 22.7 & 33.7 & $\mathrm{H}-17$ & H-15, H-17 & - & C-15, C-17, C-18 \\
\hline 17 & $1.47, \mathrm{~m}$ & $1.62, \mathrm{~m}$ & 55.1 & 51.6 & H-16, H-21 & H-16, H-21 & C-16, C-21 & - \\
\hline 18 & - & - & 44.7 & 45.1 & - & - & C-16, C-21 & - \\
\hline 19 & $1.00, \mathrm{~m}$ & $1.61, \mathrm{~m}$ & 42.1 & 41.9 & - & H-20 & C-16 & - \\
\hline 20 & $1.87, \mathrm{~m}$ & $1.81, \mathrm{~m}$ & 27.4 & 27.7 & $\mathrm{H}-21$ & H-19, H-21 & $\mathrm{C}-21$ & - \\
\hline 21 & $\begin{array}{l}2.41, \mathrm{dd} \\
(\mathrm{J}=20.0,9.2 \mathrm{~Hz})\end{array}$ & $\begin{array}{l}2.41, \mathrm{dd} \\
(\mathrm{J}=20.0,9.1 \mathrm{~Hz})\end{array}$ & 52 & 51.8 & H-17, H-20 & H-17, H-20 & $\begin{array}{l}\text { C-17, C-20, C-22, } \\
\text { C-29, C-30 }\end{array}$ & $\begin{array}{l}\text { C-15, C-17, C-20, } \\
\text { C-22, C-29, C-30 }\end{array}$ \\
\hline 22 & - & - & 72.9 & 72.8 & - & - & - & - \\
\hline 23 & $1.60, \mathrm{~s}$ & $0.88, \mathrm{~s}$ & 37.7 & 33.9 & - & - & C-3, C-4, C-24 & C-4, C-24 \\
\hline 24 & $1.27, \mathrm{~s}$ & $0.84, \mathrm{~s}$ & 23 & 22.2 & - & - & $C-4, C-23$ & C-4, C-23 \\
\hline 25 & $0.96, \mathrm{~s}$ & $0.89, \mathrm{~s}$ & 17.9 & 16.7 & - & - & C-10 & C-9, C-10 \\
\hline 26 & $1.11, \mathrm{~s}$ & $1.20, \mathrm{~s}$ & 18.9 & 16.6 & - & - & C-8, C-14 & C-8 \\
\hline 27 & $1.03, \mathrm{~s}$ & $1.33, \mathrm{~s}$ & 17.7 & 12.9 & - & - & C-14, C-15 & C-14 \\
\hline 28 & $0.95, \mathrm{~s}$ & $1.03, \mathrm{~s}$ & 16.8 & 18 & - & - & C-18 & C-18 \\
\hline 29 & $1.38, \mathrm{~s}$ & $1.38, \mathrm{~s}$ & 30.2 & 30 & - & - & C-21 & C-22 \\
\hline 30 & $1.43, \mathrm{~s}$ & $1.42, \mathrm{~s}$ & 31.7 & 31.9 & - & - & C-21 & $\mathrm{C}-22$ \\
\hline
\end{tabular}

of petroleum ether extract of the stem bark (12.1 g) using vacuum column chromatography yielded 20(29)-lupene-3 $\alpha$ ol (3,536 mg) and 20(29)-lupene-3-on (4, 63.5 mg). Compound (3) (125 mg) was also obtained from crude chloroform extract of the stem bark $(20 \mathrm{~g})$.

$6 \alpha, 22$-Dihydroxyhopane (zeorin) (1) colourless prisms (249 mg), $\mathrm{C}_{30} \mathrm{H}_{52} \mathrm{O}_{2}$, m.p. $225-227{ }^{\circ} \mathrm{C}$ (lit. m.p ${ }^{10} 221-223{ }^{\circ} \mathrm{C}$ ). UV $\left(\lambda_{\max }\right.$ EtOH) $206 \mathrm{~nm}(\log =4.63)$. IR $\left(\mathrm{KBr}, v_{\max }, \mathrm{cm}^{-1}\right)$ : 3321, 3278, 2938, 1632, 1467, 1385, 1219, 1159, 1027, 944, 762. MS $m / z$ (\% intensity): $444\left(\mathrm{M}^{+}, 0.9\right), 207$ (52), 189 (56), 161 (10), 149 (39), 109 (18), 95 (30), 69 (31), 59 (100). ${ }^{1} \mathrm{H}$ NMR and ${ }^{13} \mathrm{C}$ NMR data are tabulated in Table- 1.

$15 \alpha, 22-D i h y d r o x y h o p a n e ~(d u s t a n i n)$ (2) colourless prisms (95 mg), $\mathrm{C}_{30} \mathrm{H}_{52} \mathrm{O}_{2}$, m.p. $248-250{ }^{\circ} \mathrm{C}$ (lit. m.p. ${ }^{11} 249-250{ }^{\circ} \mathrm{C}$ ). $\mathrm{UV}\left(\lambda_{\max } \mathrm{EtOH}\right) 206 \mathrm{~nm},(\log =4.63)$. IR $\left(\mathrm{KBr}, v_{\max }, \mathrm{cm}^{-1}\right)$ : $3419,3375,2944,1463,1382,1158,1054,1035,936 . \mathrm{MS}$ $\mathrm{m} / \mathrm{z}$ (\% intensity): $444\left(\mathrm{M}^{+}, 5\right), 411$ (5), 223 (10), 205 (30), 191 (100), 163 (10), 147 (16), 135 (18), 95 (40), 69 (38), 59 (85). ${ }^{1} \mathrm{H}$ NMR and ${ }^{13} \mathrm{C}$ NMR data are tabulated in Table- 1.

20(29)-Lupene-3 $\alpha$-ol (epi-lupeol) (3) white needles (536 mg), $\mathrm{C}_{30} \mathrm{H}_{50} \mathrm{O}$, m.p. $202-204^{\circ} \mathrm{C}$ (lit. m.p. $\left.{ }^{12} 202.5^{\circ} \mathrm{C}\right)$. UV ( $\lambda_{\max }$, $\mathrm{MeOH}) 203 \mathrm{~nm}(\log =3.8)$. IR $\left(\mathrm{KBr}, v_{\max }, \mathrm{cm}^{-1}\right): 3412,3071$, 2938, 1642, 1456, 1382, 1042. MS m/z (\% intensity): $424\left(\mathrm{M}^{+}\right.$,
10), 383 (5), 272 (5), 257 (19), 234 (12), 207 (52), 189 (60), 161 (23), 147 (28), 135 (51), 121 (52), 107 (60), 95 (65), 81 (67), 68 (100). ${ }^{1} \mathrm{H}$ and ${ }^{13} \mathrm{C}$ NMR data were in good agreement with published data ${ }^{12}$.

20(29)-Lupene-3-on (lupenone) (4) colourless needles (63.5 mg), $\mathrm{C}_{30} \mathrm{H}_{48} \mathrm{O}$, m.p. $172-174{ }^{\circ} \mathrm{C}$ (lit. m.p. ${ }^{13} 170{ }^{\circ} \mathrm{C}$ ). UV $\left(\lambda_{\max }, \mathrm{MeOH}\right) 203 \mathrm{~nm}(\log =3.8)$. IR $\left(\mathrm{KBr}, v_{\max }, \mathrm{cm}^{-1}\right): 3072$, 2944, 1706, 1643, 1457, 1384. MS m/z (\% intensity): 424 ( $\mathbf{M}^{+}$, 10), 409 (9), 369 (8), 257 (9), 245 (18), 218 (24), 205 (64), 189 (24), 161 (20), 149 (22), 135 (34), 121 (38), 109 (60), 95 (57), 68 (100), 55 (60). ${ }^{1} \mathrm{H}$ and ${ }^{13} \mathrm{C}$ NMR data were in good agreement with published data ${ }^{13}$.

\section{RESULTS AND DISCUSSION}

Phytochemical investigation of leaves and stem bark of Aegle marmelos have led to the isolation of several classes of constituents including alkaloids, coumarins andtriterpenes. Our previous study reported the isolation of alkaloids and coumarins from various parts of the plant ${ }^{14,15}$. Here we wish to describe the isolation and characterization of hopane and lupane triterpenes from Aegle marmelos. Hopane triterpenes; 6 $\alpha, 22$-dihydroxyhopane (1) and 15 $\alpha, 22$-dihydroxyhopane (2) (Fig. 1) were obtained from petroleum ether crude extract of 
the leaves. The isolation of these compounds never been reported from Aegle marmelos previously while lupane triterpenes; 20(29)-lupene-3 $\alpha$-ol (3) and 20(29)-lupene-3-on (4) were isolated from petroleum ether and chloroform crude extracts of the stem bark.

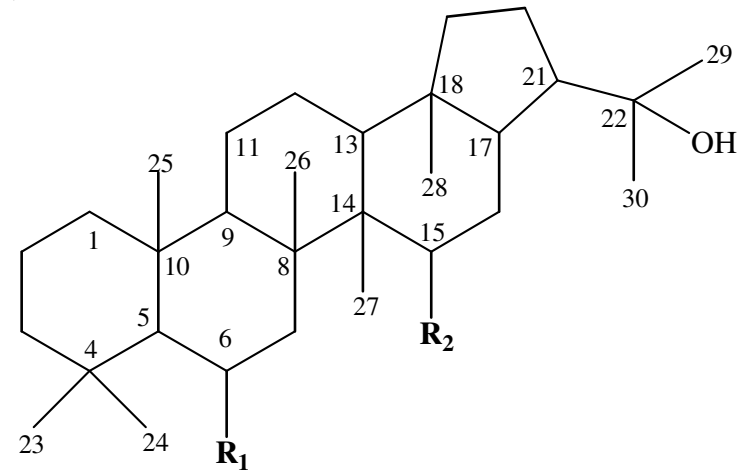

6 $\alpha, 22$-dihydroxyhopane (zeorin) (1) : $\mathrm{OH} \quad \mathrm{H}$ 15 $\alpha, 22$-dihydroxyhopane (dustanin) (2): $\mathrm{H} \quad \mathrm{OH}$

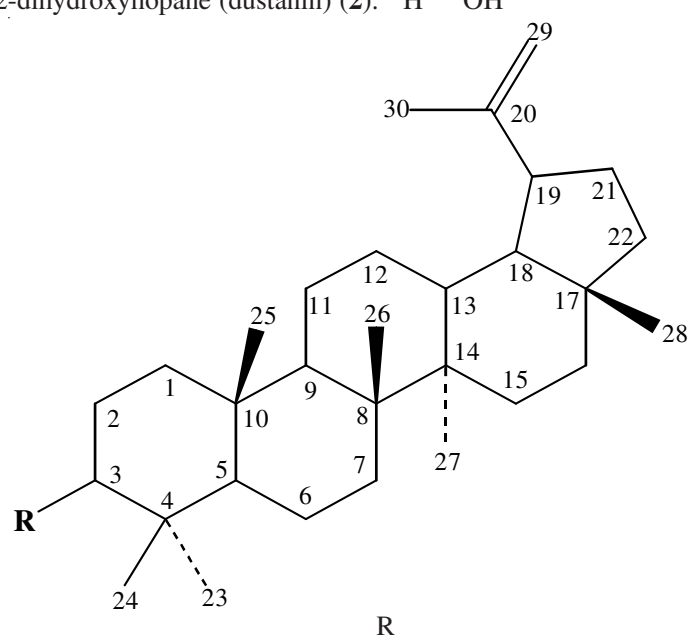

20(29)-lupene-3a-ol (epi-lupeol) (3): OH

20(29)-lupene-3-on (lupenone) (4) : =O

Fig. 1. Structures of hopane and lupane triterpenes

Compound (1) was isolated as colourless crystals (249 $\mathrm{mg}$ ), m.p. $225-227^{\circ} \mathrm{C}$ and was recrystallized from petroleum ether-acetone. The molecular ion peak at $\mathrm{m} / \mathrm{z}, 444$ corresponds to molecular formula $\mathrm{C}_{30} \mathrm{H}_{52} \mathrm{O}_{2}$. Its IR spectrum exhibited the presence of broad peak at $3321 \mathrm{~cm}^{-1}$ which corresponded to hydroxyl, aliphatic C-H stretching $\left(2938 \mathrm{~cm}^{-1}\right)$, methyl and methylene groups $\left(1632\right.$ and $\left.1385 \mathrm{~cm}^{-1}\right)$, whereas the peak at $1159 \mathrm{~cm}^{-1}$ corresponded to C-O group. The integration of ${ }^{1} \mathrm{H}$ NMR showed the presence of fifty two protons. A doublet of triplet signal appeared at downfield region at $\delta 4.23(J=10.0$, $4.5 \mathrm{~Hz}$ ) was due to $\mathrm{H}-6$ indicating the presence of hydroxyl group. H-21 peak appeared as doublet of doublet at $\delta 2.41$ $(J=20.0,9.2 \mathrm{~Hz})$, while multiplet signal at $\delta 2.18$ was correspond to H-16. Eight three-proton singlets at $\delta 1.60,1.43,1.38$, $1.27,1.11,1.03,0.96$ and 0.95 were due to methyl groups which attached to $\mathrm{C}-4\left(2 \times \mathrm{CH}_{3}\right), \mathrm{C}-10, \mathrm{C}-8, \mathrm{C}-14, \mathrm{C}-22(2 \times$ $\left.\mathrm{CH}_{3}\right)$ and $\mathrm{C}-18$. The other assignments of methylene and methine protons are summarized in Table- 1 .

${ }^{13} \mathrm{C}$ NMR spectrum revealed the presence of 30 peaks corresponds to 30 carbon atoms in the molecule. Resonances for methine carbons appeared at $\delta 61.6(\mathrm{C}-5), 68.3$ (C-6), 50.7 (C-9), 50.2 (C-13), 55.1 (C-17) and 52.0 (C-21). Signals at $\delta$ $34.6,43.4,42.6,39.8,44.7$ and 72.9 were due to quaternary carbons of C-4, C-8, C-10, C-14, C-18 and C-22 respectively. The remaining peaks correspond to other carbons of steroidal skeleton. ${ }^{13} \mathrm{C}$ NMR chemical shifts of the compound were in good agreement with the data of $6 \alpha, 22$-dihydroxyhopane reported earlier from lichen species Physcia aipolia ${ }^{10} .{ }^{1} \mathrm{H}-{ }^{1} \mathrm{H}$ COSY spectrum further confirmed the structure of compound (1) which shows the correlation between H-6, H-5 and H-7, while $\mathrm{H}-21$ correlated with $\mathrm{H}-17$ and $\mathrm{H}-20$. Its $\mathrm{HMBC}$ spectrum showed correlations between $\mathrm{H}-21$ with carbon $\mathrm{C}-17, \mathrm{C}-20$, C-22, C-29 and C-30. The details of COSY and HMBC correlation are tabulated in Table-1. 6 ,22-Dihydroxyhopane (zeorin) (1) has mostly been isolated in cryptogams such as lichen and fern. The only report of its isolation from higher plant was from Tripterygium regelii ${ }^{16}$.

The other hopane triterpenes was identified as $15 \alpha, 22-$ dihydroxyhopane (dustanin) (2) (95 mg), m.p. 248-250 ${ }^{\circ} \mathrm{C}$ and was recrystallized from acetone-methanol. The molecular ion peak appeared at $\mathrm{m} / \mathrm{z} 444$ correspond to the molecular formula $\mathrm{C}_{30} \mathrm{H}_{52} \mathrm{O}_{2}$. Its IR spectrum showed the presence of free hydroxyl group at broad peaks around 3375 and $3419 \mathrm{~cm}^{-1}$. A sharp band at $2944 \mathrm{~cm}^{-1}$ indicated the presence of aliphatic C-H bond, while peak at $1158 \mathrm{~cm}^{-1}$ was due to $\mathrm{C}-\mathrm{O}$ stretching bond. The ${ }^{1} \mathrm{H}$ NMR data summarized in Table-1 showed almost similar with that of compound (1). The appearance of doublet of doublet signal at downfield region at $\delta 4.11(J=9.7,5.1 \mathrm{~Hz})$ suggested the presence of hydroxyl group at position $\mathrm{H}-15$. Similar to compound (1), H-21 appeared as doublet of doublet signal at $\delta 2.41(J=20.0,9.1 \mathrm{~Hz})$, while doublet of doublet of doublet at $\delta 2.80(J=9.7,5.1,2.0 \mathrm{~Hz})$ was attributed to $\mathrm{H}-16$.

The ${ }^{1} \mathrm{H}$ and ${ }^{13} \mathrm{C}$ NMR spectra also showed the presence of eight methyl groups at $\delta 33.9$ (C-23), 22.2 (C-24), 16.7 (C25), 16.6 (C-26), 12.9 (C-27), 18.0 (C-28), 30.0 (C-29) and 31.9 (C-30) corresponded to $\delta 0.88,0.84,0.89,1.20,1.33$, $1.03,1.38$ and 1.42 , respectively. The signals at $\delta 74.9(\mathrm{C}-15)$, 56.7 (C-5), 51.8 (C-21), 51.6 (C-17), 51.5 (C-9) and 50.0 (C13) represent the methine carbons. Signal for $C-22$ appeared at lower field at $\delta 72.8$ which due to deshielding effect of hydroxyl group. The quaternary carbons appeared at $\delta 48.1$ (C-14), 45.1 (C-18), 44.2 (C-8), 38.3 (C-10) and 34.3 (C-4). The ${ }^{13} \mathrm{C}$ NMR data were also compared with the data reported previously ${ }^{17}$. COSY spectrum showed correlations between $\mathrm{H}-15$ and $\mathrm{H}-16$; between $\mathrm{H}-21$ with $\mathrm{H}-17$ and $\mathrm{H}-20$. HMBC spectrum shows long range coupling of proton $\mathrm{H}-15$ with carbon C-8, C-14, C-16 and C-27, while proton $\mathrm{H}-21$ correlates with carbon C-15, C-17, C-20, C-22, C-29 and C-30. Full COSY and HMBC correlation data can be referred in Table-1. To our knowledge, this is the first isolation of $15 \alpha, 22-$ dihydroxyhopane (dustanin) (2) from higher plant.

Meanwhile, two lupane triterpenes; epi-lupeol (3) and lupenone (4) were isolated from the stem bark of Aegle marmelos. 20(29)-lupene-3 $\alpha$-ol or epi-lupeol, (3) (536 mg) was obtained from petroleum ether and chloroform extracts. The compound appears as white needles with melting point 202-204 ${ }^{\circ} \mathrm{C}$. The appearance of molecular ion peak at $\mathrm{m} / \mathrm{z}, 426$ corresponds to molecular formula $\mathrm{C}_{30} \mathrm{H}_{50} \mathrm{O}$. Its IR spectrum 
revealed the presence of hydroxyl group $\left(3412 \mathrm{~cm}^{-1}\right)$, aromatic and aliphatic $\mathrm{C}-\mathrm{H}$ bonding (3071 and $2938 \mathrm{~cm}^{-1}$ ), while absorption peak for $\mathrm{C}=\mathrm{C}, \mathrm{CH}_{3}$ and $\mathrm{C}-\mathrm{O}$ groups were at 1642 , 1382 and $1042 \mathrm{~cm}^{-1}$, respectively. The compound has been identified as 20(29)-lupene-3 $\alpha$-ol (3) and its NMR data were in good agreement with the reported data ${ }^{12}$. Compound (4) was identified as 20(29)-lupene-3-on or lupenone (63.5 mg) and was obtained from petroleum ether extract. The compound appeared as colourless needle crystals with melting point at $172-174{ }^{\circ} \mathrm{C}$ and recrystallized in petroleum ether-acetone. The mass spectrum showed molecular ion peak at $\mathrm{m} / \mathrm{z} 424$ which corresponds to molecular formula $\mathrm{C}_{30} \mathrm{H}_{48} \mathrm{O}$. Its IR spectrum exhibited the similar absorption peak to compound (3) but with an additional peak at $1706 \mathrm{~cm}^{-1}$ due to the presence of $\mathrm{C}=\mathrm{O}$ group. The compound was identified as 20(29)-lupene3-on (4) based on similarity of its physical and spectral data with literature values ${ }^{4}$.

\section{Conclusion}

Phytochemical investigation on Aegle marmelos originated from Yogjakarta, Indonesia has afforded two hopane triterpenes from the petroleum ether crude extract of the leaves and two lupane triterpenes isolated from the stem bark. To our best of knowledge the hopane triterpenes were found to be the first time isolated from Aegle marmelos collected from Yogyakarta, Indonesia.

\section{ACKNOWLEDGEMENTS}

The authors thank School of Graduate Studies (UPM) for Graduate Research Fellowship (GRF) awarded to one of the authors (S. Ahmad) and staff of Department of Chemistry (UPM) for the technical assistant and facilities provided.

\section{REFERENCES}

1. R. Bentley and H. Trimen, Medicinal Plants, vol. 1. New Burlington street: London J \& A. Churchill, First Reprint 1983 New Delhi, International Book Distributor (1880).

2. A.M. Abeysekera, K.T.D. De Silva, S. Samarasinghe and P.A.K. Seneviratne, Fitoterapia, 67, 367 (1996).

3. D. Basu and R. Sen, Phytochemistry, 13, 2330 (1974).

4. M.D. Manandhar, A. Shoeb, R.S. Kapil and S.P. Popli, Phytochemistry, 17, 1814 (1978).

5. S.N. Garg, M.S. Siddiqui and S.K. Agarwal, J. Essent. Oil Res., 7, 283 (1995).

6. B.R. Sharma, R.K. Rattan and P. Sharma, Phytochemistry, 20, 2606 (1981).

7. S.D. Srivastava, S. Srivastava and S.K. Srivastava, Fitoterapia, 67, 83 (1996).

8. T.R. Govindachari and M.S. Remila, Phytochemistry, 22, 755 (1983).

9. K. Ohashi, H. Watanabe, Y. Okumura, T. Uji and I. Kitagawa, Chem. Pharm. Bull., 42, 1924 (1994).

10. J.A. Elix, A.A. Whitton and A.J. Jones, Aust. J. Chem., 35, 641 (1982).

11. R.E. Corbett and A.L. Wilkins, Aust. J. Chem., 30, 2333 (1977).

12. J. Buckingham, F.M. Macdonald and H.M. Bradley, Dictionary of Natural Products, 4, London: Chapman and Hall (1994).

13. T.K. Razdan, S. Harkar, B. Qadri, M.A. Qurishi and M.A. Khuroo, Phytochemistry, 27, 1892 (1988).

14. S. Riyanto, M.A. Sukari, M. Rahmani, A.R. Manas, A.M. Ali, U.K. Yusuf and R. Muse, J. Trop. Med. Plants, 3 (2002).

15. S. Riyanto, M.A. Sukari, M. Rahmani, G.C.L. Ee, Y.H. Taufiq-Yap, N. Aimi and M. Kitajima, Malaysian J. Anal. Sci., 7, 463 (2001).

16. S. Inayama, H. Hori, G.M. Pang, H. Nagasawa and H. Ageta, Chem. Pharm. Bull., 37, 2836 (1989).

17. G.W. Van Eijk, H.J. Roeijmans and D. Seykens, Tetrahedron Lett., 27, 2533 (1986). 